Volume I Tahun 2021

November 2021
E-ISSN: $2808-5361$
http://e-journal.fkmumj.ac.id/
Proceeding The First Muhammadiyah InternasionalPublic Health and Medicine Conference

\title{
The Role of The Community in Handling The Covid-19 Pandemic in Indonesia
}

\author{
Abdul Rohim \\ Master of Public Health Program of Public Health Faculty, University Muhamadiyah Jakarta, \\ K.H. Ahmad Dahlan St, Cireundeu, Ciputat South Jakarta, 151419 \\ E-mail: abdulrohim045@gmail.com
}

\begin{abstract}
Coronavirus disease is also known as Covid-19 (Corona Virus Disease 2019) and was discovered in the city of Wuhan, China at the end of December 2019. This virus spreads rapidly and has reached almost every country, including Indonesia, in just a few months. As a result, numerous countries have implemented regulations imposing lockdowns to prevent the spread of the Coronavirus. To control the spread of this virus, Indonesia implemented a Large-Scale Social Restriction (PSBB) policy. The method employed in this study is to analyze data from various reading sources. By comparing journals or articles, references are obtained from online publications with diverse studies. This study utilized five journals as references, all of which demonstrated that community participation in preventing the spread of Covid-19 was in a good category. According to the journals reviewed, information regarding the handling of Covid-19 necessitated the participation of all parties to prevent its spread. From the five journals obtained, all of these journals indicate that the role of the community is required in preventing the spread of the Covid-19 virus.
\end{abstract}

Keywords: Covid-19 Virus, Prevention, Community 


\section{INTRODUCTION}

Coronavirus, generally known as SARS-CoV-2 (severe acute respiratory syndrome coronavirus), is a virus that attacks the respiratory system. The disease caused by this viral infection is called Covid-19. Coronavirus can cause mild respiratory problems, serious lung infections, and even death. The Coronavirus, also known as the Severe Acute Respiratory Syndrome Coronavirus 2 (SARS-CoV-2) is a new type of coronavirus that is transferred to humans. This virus can infect anyone, including the elderly, adults, children, and infants, as well as pregnant women and breastfeeding mothers. Coronavirus infection is called Covid-19 (Corona Virus Disease 2019) and was first discovered in the city of Wuhan, China at the end of December 2019. This virus spreads rapidly and has contaminated almost every country, including Indonesia, in a few months. As a result, several countries have implemented regulations imposing lockdowns to prevent the spread of the Coronavirus. To prevent the spread of this virus, Indonesia implemented a Large-Scale Social Restriction (PSBB) policy. ${ }^{1}$

According to Rusidi in Siregar (2001), there are four types of public participation: first, the contribution of thoughts (ideas); second, the contribution of material (goods, funds, and tools); third, the contribution of energy (work); and the fourth is utilization and implementation of development services. According to Muarifuddin (2017), the form of participation in the community's social system involves materials, ideas, and energy. Community involvement extends not just to employees involved in its implementation, but also to decision-making to enjoying the results. This type of community participation in preventing the coronavirus has begun to emerge in the face of Covid-19 from all levels of society. The support begins with motivation for medical workers, decision-making in the covid cluster, personal protective equipment, masks made by local tailors, hand sanitizers made independently, supplying water as a means of washing hands for people to use in public places, and other activities. ${ }^{2}$

In Indonesia, public awareness of the government's appeal to break the chain of Covid-19 spread is still inadequate, as seen by the high number of community activities outside the home. This paper aims to analyze community participation in preventing the spread of the Covid-19 pandemic in Indonesia. The crucial step to preventing the spread of the Covid-19 pandemic is community participation. To break the virus's chain of transmission, the government recommends the society implement social distancing (social restrictions) and physical distancing (physical restrictions). Some people obey the social restriction mechanism deliberately and critically, while others do not. ${ }^{3}$

\section{METHODS}

The method employed in this study is to analyze data from various reading sources. References are taken from online journals with different studies by comparing journals or articles with 
one another. The method employed in this study is to collect information from various sources, including research findings.

\section{RESULTS AND DISCUSSIONS}

This study employed 5 journals as references. The following journals were used as references:

1. Enhancing Community Participation in Covid-19 Prevention in Maduretno Village, Papar District, Kediri Regency.

2. The Community's Role in Reducing the Covid 19 Eradication Rate in Tanah Datar Regency

3. Community Empowerment Efforts in Covid-19 Prevention and Control With "Gotong Royong Jogotonggo" in RW VIII and RW X, Jomboran Village, Central Klaten - Klaten

4. Behavior and Role of Community Leaders in the Prevention and Management of the Covid-19 Pandemic in Jayaraga Village, Garut Regency.

5. Enhancing Community Participation in Preventing the Spread of the Covid-19 Virus

The five selected journals were conducted on the Indonesian islands of Java and Sumatra in 2020 and 2021, and all of the journals demonstrated that community participation in preventing the spread of Covid-19 is in a good category. $4,5,6,7,8$

The first journal entitled Enhancing Community Participation in Covid-19 Prevention in Maduretno Village, Papar District, Kediri Regency, was conducted by Dwi Ertiana, Maria Ulfa, Aspiyani, Silaturrokhmah, and Nur Widya Yuda Prastiwi from the Midwifery Study Program STIKES Karya Husada Kediri, Kediri, Indonesia. This research was published in Darmabakti Journal of Community Service and Empowerment in 2020. This research was conducted on June 18-28, 2020 in the form of community service activities, namely village heads, and village officials, members of Tunas Muda youth organization, Maduretno villagers, Papar District, Kediri Regency. Activities included the formation of a task force from Maduretno Village, the creation of the Covid Village Alert Post, the establishment of a newcomer reporting flow, outreach to all members of Tunas Muda youth organization, counseling to village officials and the community, spraying door to door disinfectants, providing information by commuting cars, installation of leaflets to prevent the spread of Covid-19 and distribution of masks. There were 32 people (91\%) out of the 35 Tunas Muda youth organizations who participated in the socialization process. Regarding counseling to village officials and community leaders, from 50 people who were invited, only 46 people (92\%) could attend the invitation. Spraying disinfectant door to door for 11-12 people per sub-village as many as 3 sub-villages. After the socialization was carried out to the members of the Tunas Muda youth organization, $100 \%$ of the members were able to practice properly the correct way of spraying. For the production of disinfection liquid, 32 people (94.1\%) are capable of making disinfectant liquid correctly. There was an increase in knowledge from village officials and community leaders present at the time of 
counseling, with 35 people (70\%) having strong knowledge, 11 people (22\%) having enough knowledge, 4 people (8\%) lacked knowledge. ${ }^{4}$

The second journal entitled The Community's Role in Reducing the Covid-19 Eradication Rate in Tanah Datar Regency was researched by Fadjri Wahyu, Dian Flora, Desni Yulinda, Tri Yuliani, Irwandi, Iswadi, Novi Budiman, and Beni Putra Hanafi from the State Islamic Institute of Batusangkar, Indonesia. This research was published by Alfuad, the Religious Social Scientific Journal in 2020. This study used qualitative research methods to analyze literature (documents) from a variety of sources, including printed and electronic media, as well as electronic books and journals. Implementation of data in descriptive form employing data collecting methods such as interviews, literature reviews, and historical, comparative, and critical polyvocalistic approaches. The study's findings reveal that to eradicate the pandemic in the Tanah Datar Regency area, the community and the government must work together. The community must also participate in several lines of disaster management activities carried out by the government. The community may help by beginning with themselves, their families, and the communal environment that is capable of containing the spread of the pandemic. Communities can mobilize self-awareness of each region, particularly the smallest environment, to shift the paradigm that we need to preserve and adopt a healthy and clean lifestyle, avoid crowds, and carry out activities from home. Socialization of the surrounding community can support the government's entire program, allowing them to work together to overcome natural disasters in our area, particularly in the Tanah Datar Regency. The community is vital to the success of the government's program to eradicate the Covid-19 outbreak. ${ }^{5}$

The third journal entitled Community Empowerment Efforts in Prevention and Control of Covid-19 With "Gotong Royong Jogotonggo" in RW VIII and RW X Jomboran Village, Central Klaten - Klaten was researched by Istianna Nurhidayati, Sri Handayani, and Ratna Agustiningrum from the Nursing Study Program of STIKES Muhammadiyah Klaten. This research was published in the Journal of the Health Service of STIKES Cendekia Utama Kudus in 2021. This study was carried out through community service activities and community empowerment efforts in preventing and controlling Covid-19, with the first step being outreach to the community and community leaders on what, goals, targets, and how to implement "Gotong Royong Jogo Tonggo." The second stage is training for health cadres and youth organizations to carry out programs that have been prepared including the use of personal protective equipment, washing hands with soap, using thermogenic and preparing self-isolation houses, monitoring health and signs of symptoms, providing necessities to community members affected by Covid-19. The third stage is monitoring and evaluating activities. According to the findings of his research, there are still many people who are refusing to comply with the government's call to prevent the coronavirus epidemic, which is driven by cognitive bias. According to the research findings, people do not follow the Covid-19 pandemic protocol because 
they do not comprehend the risk of getting Covid-19, the aim of prevention, and how to apply PPE procedures. The community reacted well to this initiative. Cadres and members of the community collaborate to prevent the spread of Covid-19. ${ }^{6}$

The fourth journal entitled Behavior and Role of Community Leaders in the Prevention and Management of the Covid-19 Pandemic in Jayaraga Village, Garut Regency was conducted by Udin Rosidin, Laili Rahayuwati, and Erna Herawati from the Faculty of Nursing, Padjadjaran University. The research was published in the Umbara Indonesian Journal of Anthropology in 2020. This study was followed by 64 community leaders who participated voluntarily. They are the government's elite community consisting of village officials, RW officials, and health cadres from each RW. The data collection method was accomplished through discussion in the Whatsapp group. The researcher asked the questions in the Whatsapp group, and the informants in the group responded directly. The informants' responses were summarized and categorized, then analyzed according to the principles in qualitative data analysis. The following is an elaboration of questions from the three components of the knowledge domain about Covid-19 and its relationship to PHBS, Attitudes toward Covid-19, and Covid-19 preventative methods. According to the study's findings, community leaders in Jayaraga Village developed their behavior in preventing Covid-19 by acquiring appropriate knowledge about Covid-19 and how to prevent it. This understanding informs their concern about the virus's rapid spread. That anxiety, however, does not frighten them since they know how to avoid it. Knowledge and attitude then motivate them to act to prevent and cope. They begin their deeds within themselves, their families, and then spread to society. In the context of the Covid-19 pandemic, the steps performed by the community leaders above demonstrate their active involvement as government elites in society. ${ }^{7}$

The fifth journal entitled Enhancing Community Participation in Preventing the Spread of the Covid-19 Virus was conducted by Sujito, Dwi Haryoto, Hari Wisodo, Arif Hidayat, and Hestiningtyas Yuli Pratiwi from the State University of Malang. This research was published in JPM (Journal of Community Empowerment) in 2021. Activities in the form of community service were carried out in RW 012, Merjosari Village, Lowokwaru District, Malang City. The service was conducted from July to November 2020. The activities carried out include socialization, optimization of resources, monitoring, and evaluation of activities regarding the prevention of Covid-19. The respondents for this study were 86 people from RW 012 Merjosari Village. The results revealed that the team's service was well accepted by the residents of RW 12 Merjosari Village in Malang City. 95.33 percent of residents who responded to the implementation were positive, while only 4.67 percent were negative. Residents who infrequently attend this service activity are among the negative responders. This questionnaire also elicits information about public awareness. It was discovered that as many as 80 
percent of those who completed the questionnaire strongly agreed, while the rest concurred. This suggests that all residents agree that environmental health awareness is increasing. ${ }^{8}$

\section{CONCLUSIONS AND SUGGESTIONS}

According to the journals reviewed, knowledge regarding the handling of Covid-19 necessitates the cooperation of all stakeholders to prevent its spread. The five publications obtained all indicate that the community's participation in preventing the spread of the Covid-19 virus is required. Handling must also be quick, thus health personnel must perform the detection accuracy. So that the number of victims is not increased. In this case, the government has also given preventive methods, such as instructions to always maintain health, wear masks, keep a safe distance, practice proper cough etiquette, stay at home, and only leave the house if necessary. However, there are still many people who do not obey this regulation, and there are also many people who have implemented this procedure to protect themselves and their families from Covid-19. Health workers and the community should be able to avoid this Covid-19 with the engagement of the community, community leaders, and health workers, however, there is a need for self-awareness in people who still do not obey these regulations. Because there are still many people who do not think this regulation is important. It is expected that all villages will be developed as resilient villages in the face of the Covid-19 pandemic so that the community understands the importance of implementing the correct health measures, as demonstrated in several villages on both Java and Sumatra.

\section{REFERENCES}

1. Siti Khodijah Afsas, Muhammad Hadi Kusumah, Leoris Hemanda Putri, Bella Rosalia Wangi, Ilham Nur Syafaad. Peran Masyarakat Dalam Membantu Memutus Mata Rantai Penyebaran Covid-19 Dengan Meningkatkan Imunitas Tubuh Di Era New Normal. Universitas Negeri Semarang. 2020.

2. Yudan Hermawan, Akhmad Rofiq. Partisipasi Masyarakat Dalam Pencegahan Covid-19. Journal of Nonformal Education and Community Empowerment Volume 4 (1): 17-22, Juni 2020.

3. Mohammad Mulyadi. Partisipasi Masyarakat Dalam Penanganan Penyebaran Covid-19. Kajian Singkat Terhadap Isu Aktual Dan Strategis. Vol. XII. April/2020.

4. Dwi Ertiana, Maria Ulfa, Aspiyani, Silaturrokhmah, dan Nur Widya Yuda Prastiwi. Peningkatan Peran Serta Masyarakat Dalam Pencegahan Covid-19 di Desa Maduretno Kecamatan Papar Kabupaten Kediri. Jurnal Pengabdian dan Pemberdayaan Masyarakat 01-02 (2020) 023-033.

5. Fadjri Wahyu, Dian Flora, Desni Yulinda, Tri Yuliani, Irwandi, Iswadi, Novi Budiman, dan Beni Putra Hanafi. Peran Masyarakat Dalam Menekan Laju Pemberantasan Covid-19 Di Kabupaten Tanah Datar. Alfuad Jurnal. Volume 4. December 2020, Page 40 - 52. 
6. Istianna Nurhidayati, Sri Handayani, Ratna Agustiningrum. Upaya Pemberdayaan Masyarakat Dalam Pencegahan Dan Pengendalian Covid-19 Dengan "Gotong Royong Jogotonggo" Di RW VIII Dan RW X Desa Jomboran Klaten Tengah - Klaten. Jurnal Pengabdian Kesehatan STIKES Cendekia Utama Kudus. Vol. 4, No. 1, Januari 2021.

7. Udin Rosidin, Laili Rahayuwati dan Erna Herawati. Perilaku dan Peran Tokoh Masyarakat dalam Pencegahan dan Penanggulangan Pandemi Covid -19 di Desa Jayaraga, Kabupaten Garut. Umbara Indonesian Journal of Anthropology. Volume 5 (1) Juli 2020.

8. Sujito, Dwi Haryoto, Hari Wisodo, Arif Hidayat, dan Hestiningtyas Yuli Pratiwi. Meningkatkan Peran Serta Masyarakat Dalam Mencegah Penyebaran Virus Covid-19. JPM (Jurnal Pemberdayaan Masyarakat). Vol.6 No.1. 2021. 
Volume I Tahun 2021

November 2021
E-ISSN: 2808-5361

http://e-journal.fkmumj.ac.id/
Proceeding The First Muhammadiyah InternasionalPublic Health and Medicine Conference 